Journal of Agricultural Sciences
(Tarim Bilimleri Dergisi)

\title{
The Effect of Neutral Electrolyzed Water on the Microbial Population and Quality of Dried Figs (Ficus carica L.) During Storage
}

\author{
Çiğdem YAMANER ${ }^{\mathrm{a}}$ (i)

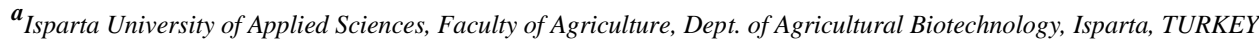 \\ ARTICLE INFO \\ Research Article \\ Corresponding Author: Çiğgdem YAMANER, E-mail: cigdemyamaner@isparta.edu.tr \\ Received: 31 October 2020 / Revised: 01 May 2021 / Accepted: 01 May 2021 / Online: 25 March 2022
}

\section{ABSTRACT}

Fig is one of economically the most important agricultural products and preserving its quality is of crucial importance. In this study, the efficiency of Neutral Electrolyzed Water (NEW) in the controlling of the microbial load of dried figs was researched. For this reason, it was used three different fig groups. The first group was washed with $10 \% \mathrm{NEW}$, the second group was washed with $6 \%$ salty water at $50{ }^{\circ} \mathrm{C}$ for $1 \mathrm{~min}$, and finally, the third group did not wash as control group. The samples were taken at the beginning of the storage and in monthly periods through 6 months. Initial average amount of mesophilic aerophilic bacteria (MAB) was $3.89 \log \mathrm{cfu} \mathrm{g}^{-1}$. This amount was reduced to $0.73 \log \mathrm{cfu} \mathrm{g}^{-1}$ after 6 months storage in the group washed with NEW and $2.52 \operatorname{log~cfu~g}^{-1}$ in the group washed with salty water. The yeast-mold number was reduced from $3.08 \log \mathrm{cfu} \mathrm{g}^{-1}$ to $0.96 \mathrm{log} \mathrm{cfu} \mathrm{g}^{-1}$ in the group washed with NEW and 1.9 $\log \mathrm{cfu} \mathrm{g}^{-1}$ in the group washed with salty water at the end of the 2 nd month. It was determined that both applications in comparison with the control group did not cause an important change in physical and chemical parameters such as colour and $\mathrm{pH}$ of dried figs. These results show that NEW can be used as a more safe and effective method in reducing the microbial load in comparison with the standard application.

Keywords: Ficus carica L., Colour and pH of dried figs, Microbial load, Neutral electrolyzed water (new), Salty water

(C) Ankara University, Faculty of Agriculture

\section{Introduction}

Fig (Ficus carica L.) is an economically valuable and highly valued fruit. Its growing area is mostly the Mediterranean region (Stover et al. 2007) in which mild winters and hot dry summers are typical seasonal characteristics. In Turkey, it mainly grows in the Aegean region. With the yearly production of fresh figs of 306.499 tons (TUIK, 2018/2019) and dried fig of 72.000 tons (FAO, 2016/2017), Turkey ranks the first in the World in fig production.

Figs are generally dried on racks under the sun and among critical foods for microbiological contamination at the stages of harvesting, drying, storing, shipment and processing. They are generally contaminated with Escherichia coli, Bacillus cereus and its spores, Penicillium spp. and Aspergillus spp. (Frazier \& Westhoff 1988; Boudra et al. 1994). The number of the microorganisms in the dried figs can reach up to $10^{7}-10^{8} \mathrm{cfu} \mathrm{g}^{-1}$ under poor storage conditions and especially in inadequate storage conditions. Inadequate storage conditions increase aflatoxin (AF), ochratoxin A, and fumonisin risk which can cause hepatocellular carcinoma and cancer and immunosuppression for humans. Boudra et al. (1994) reported that the highest level of AF levels of dried figs was determined 6 times higher than fresh frigs and also, 30 times higher than unripe ones.

In routine Turkish plants, dried figs are first washed with salty $(3-6 \% \mathrm{NaCl})$ high-temperature water $\left(60-80{ }^{\circ} \mathrm{C}\right)$ to reduce surface contamination and soften them.

One of the feasible alternatives to salty hot water can be electrochemical disinfection including acid electrolyzed water (AEW) and neutral electrolyzed water (NEW). Electrolyzed water is generated in electrolysis chamber, through anodes and cathodes separated by an ion-permeable membrane, using sodium chloride water solution. This process produces chlorine compounds such as hypochlorous acid $(\mathrm{HOCl})$, hypochlorite ions $\left(\mathrm{ClO}^{-}\right)$and chlorine $\left(\mathrm{Cl}_{2}\right)(\mathrm{Guentzel}$ et al. 2010). These compounds are responsible for the effectiveness of electrolyzed water. It has been well documented that AEW has a strong bactericidal and antifungal effect against various microorganisms, attached to fruit and vegetables, including Escherichia coli, Bacillus cereus, and Bacillus subtilis (Ileri et al. 2006; Ding et al. 2011; Graça et al. 2011; Hao et al. 2011). Although having potential antimicrobial activity, AEW has a relatively low $\mathrm{pH}$ of 2-3 at which $\mathrm{Cl}_{2}$ is easy to volatilize into the air which consequently poses threat to health. Moreover, AEW may be corrosive to organic materials due to its high acidity, which ultimately limits its application (Rahman et al. 2010). 
In theory, the main types of chlorine in electrolyzed water are $\mathrm{HOCl}$ and $\mathrm{ClO}^{-}$at $\mathrm{pH}$ between 6.0 and 9.0 (White 1998). NEW has a neutral $\mathrm{pH}$ of 7-8, resulting in less corrosion of contact surfaces and greater stability of chlorine agents (Len et al. 2002). It has been shown that NEW has strong antibacterial or antifungal, or anti-mycotoxigenic effect against Yersinia enterocolitica, E. coli, Candida lambica in fresh-cut vegetable washing water (Lehto et al. 2017), Colletotrichum fructicola on strawberry (Hirayama et al. 2016), indigenous flora of cabbage and carrot (Lee et al. 2014), Alycyclobacillus acidoterrestris spores on apples (Torlak 2014), mesophilic bacteria, psychrophilic bacteria, enterobacteria, yeast and molds in broccoli (Navarro-Rico et al. 2014), E. coli O157:H7, Salmonella enteretidis and Listeria monocytogenes on the surface of tomatoes (Deza et al. 2003), E. coli, spores of Bacillus cereus, Aspergillus flavus, Penicillium expansum isolated of fig fruit (Yamaner et al. 2016), and aflatoxincontaminated Maize (Jardon-Xicotencatl et al. 2015).

The aim of this study is to assess the efficiency of NEW as a disinfectant in reducing total number of mesophilic aerophilic bacteria (MAB), yeasts and mold on dried figs stored at room temperature for 6 months by comparison with salty water which is a routine process in Turkey. This is the first study about NEW effects on microbial load and physicochemical properties of dried figs.

\section{Material and Methods}

\section{1. The preparation of neutral electrolyzed water}

NEW was obtained by electrolysis of a mixture of $\mathrm{NaCl}\left(20 \mathrm{~g} \mathrm{~L}^{-1}\right)$ and tap water using STEL-10H-120-01 generator (STEL $10 \mathrm{H}-120-01$, Russia) at $40.0 \mathrm{~V}, 9.0 \mathrm{~A}$ and a rate of $250 \mathrm{~mL} / 22 \mathrm{sec}$. NEW dilutions were prepared by using sterile tap water, prepared by autoclaving at $121^{\circ} \mathrm{C}$ for $15 \mathrm{~min}$, at rates of $10 \%$. The concentration of NEW and the time of exposure to the washing treatments was selected based on previous studies (Yamaner et al. 2016). Analytical indices [Oxidation Reduction Potential (ORR), $\mathrm{pH}$ and available chlorine concentration (ACC)] of the treated solutions were measured immediately after $10 \% \mathrm{NEW}$ preparation. The $\mathrm{pH}$ was measured with a $\mathrm{pH}$ meter (HI 2211-02, HANNA, USA), and ORP was measured with an ORP meter (HI98120, HANNA, USA). The pH meter was calibrated using commercial standard buffers at pH 4.0 and 7.0 (Merck Ltd., Germany). The ACC was measured on the basis of the iodometric method reported by Dychdala (1983).

\section{2. Washing the figs and storing the samples}

In this study, while one fig group was washed with $10 \% \mathrm{NEW}$, the other group was washed with $6 \%$ salty water which is the standard practice. Samples in the third group were stored as control group without any processing. The washing processes were performed for $1 \mathrm{~min}$ at $50{ }^{\circ} \mathrm{C}$ in a laboratory setting. After washing, each group was stored from November to May.

\section{3. Determining microbial load of samples}

Ten fig samples from each group were randomly chosen at the beginning of the storage and in monthly periods for determining microbial load. By taking small parts of $1 \mathrm{~g}$ from the exterior surface of each of these samples under aseptic conditions, a total of $10 \mathrm{~g}$ sample was prepared. This sample was transferred into sterile peptone water $(0.1 \mathrm{w} / \mathrm{v} \%)$ and stirred in a magnetic stirrer for 5 minutes to homogenize the sample (Öztekin et al. 2006). Ten-fold dilutions were prepared from homogenate. $1 \mathrm{~mL}$ was taken from each dilution rate and inoculations were performed by using surface spread method to Nutrient Agar (NA) (Merck $\mathrm{KGaA}$, Germany) for the total MAB count and to Potato Dextrose Agar (PDA) (Merck KGaA, Germany) (its pH was reduced to 3.5 with $10 \%$ lactic acid) for the yeast and molds count. The NA plates were incubated at $30{ }^{\circ} \mathrm{C}$ for $48 \mathrm{~h}$, while PDA plates were incubated at $25^{\circ} \mathrm{C}$ for 3-5 days (Messer et al. 2000). The inoculations were carried out with 3 parallels in 3 repetitions. After incubation, the colonies of the microorganisms were counted and results were recorded. Count of totally MAB and yeastmold was calculated as $\log$ colony forming unit per gram $\left(\log \mathrm{cfu} \mathrm{g}^{-1}\right)$.

\section{4. Physicochemical analyses}

$\mathrm{pH}$ values of the dried figs were determined with a pH meter (HI 2211-02, HANNA, USA), according to AOAC (1990) method 970.21. The colour of the samples was measured with a Minolta chromameter (Minolta, model CR310, Osaka, Japan) (Cemeroğlu 2007). Using L*, a*, b* values according to Mohammadi et al. (2008), the browning index (B.I) was calculated. Moisture contents of the samples were determined using dried fruit moisture tester meter - Type A series (DFA of California, PO Box 270A, Santa Clara). The conductivity values obtained were converted into \% moisture content from the device's conversion table. For water activity measurement, fruit at room temperature were minced. The pulps were placed in the TESTO 650 reference measurement device and their water activity was read (Cemeroğlu 2007). All physicochemical analyses were carried out with 10 fig samples from each group.

\section{5. Statistical analysis}

All experiments were of complete randomised design and carried out with 3 parallels in 3 repetitions. Results were analysed by One-way ANOVA using the Duncan's multiple range test $(\mathrm{P}<0.05)$ to determine differences in effects of treatments on microbial 
inactivation. The statistical analyses were performed with SPSS (version 15.0).

\section{Results and Discussion}

\section{1. Physicochemical properties of NEW solution.}

To facilitate the NEW usage for fig process, $10 \%$ NEW concentrations were prepared by tap water. The ORP, pH and ACC for the treated solutions (NEW) are shown in Table 1.

Table 1- Physicochemical properties of $10 \%$ NEW solution

\begin{tabular}{lc}
\hline Concentrations (\%) & 10 \\
\hline $\mathrm{pH}$ & 7.65 \\
$\mathrm{EC}(\mathrm{mS})$ & 2.5 \\
$\mathrm{ORP}(\mathrm{mV})$ & 855 \\
$\mathrm{ACC}(\mathrm{ppm})$ & 71.4 \\
\hline
\end{tabular}

ACC composes of $\mathrm{Cl}_{2}$ gas, $\mathrm{HOCl}$ and $\mathrm{ClO}^{-}$. Composition of $\mathrm{ACC}(\%)$ in $\mathrm{EW}$ changes depending to $\mathrm{pH}$ values. At lower $\mathrm{pH}$ (0-2.0), chlorine exists in gas form. $\mathrm{Cl}_{2}$ proportion decreases as $\mathrm{pH}$ value increases. At $\mathrm{pH}$ 5.0-6.5, $\mathrm{HOCl}$ concentration is the highest amount. As $\mathrm{pH}$ increases, $\mathrm{HOCl}$ dissociates into $\mathrm{ClO}^{-}$(Rahman et al. 2016). In this study, 10\% $\mathrm{NEW}$ was produced which has $7.65 \mathrm{pH}$ and $71.4 \mathrm{ppm}$ ACC values. Therefore, predominant composition of ACC in this solution consists of $\mathrm{HOCl}$ and $\mathrm{ClO}$.

\section{2. Microbiological analysis results}

In this study, MAB and yeast-mold loads of samples were determined before and after the washings for understanding the effectiveness of NEW on microbial loads (Tables 2 and 3). Dried figs wait between 3-6 months until they reach the consumer from the post-harvest producer warehouses, wholesaler warehouses and finally the warehouses of the fig processing plants. Considering these storage periods, the study is established on a 6-month storage period.

Table 2- Efficacy of treatment solutions (10\% NEW and $6 \%$ salty water) against MAB load on surface of dried figs during the storage time*

\begin{tabular}{|c|c|c|c|c|c|c|c|c|}
\hline \multirow[t]{3}{*}{ Treatments } & & \multicolumn{7}{|c|}{ Storage Time (Month) } \\
\hline & $\begin{array}{c}\text { Before } \\
\text { washing }\end{array}$ & $\begin{array}{c}\text { After } \\
\text { washing }\end{array}$ & 1 & 2 & 3 & 4 & 5 & 6 \\
\hline & \multicolumn{2}{|c|}{$M A B$ count $\left(\log c f u g^{-1}\right)$} & \multicolumn{5}{|c|}{ MAB count $\left(\log c f u g^{-1}\right)$} & \\
\hline Control & $3.89 \pm 0.05^{\mathrm{Ca}}$ & $3.89 \pm 0.05^{\mathrm{Cc}}$ & $3.35 \pm 0.00^{\mathrm{Bc}}$ & $3.33 \pm 0.05^{\mathrm{Bc}}$ & $3.24 \pm 0.07^{\mathrm{Bc}}$ & $3.25 \pm 0.07^{\mathrm{Bc}}$ & $3.04 \pm 0.03^{\mathrm{Ab}}$ & $3.27 \pm 0.11^{\mathrm{Bb}}$ \\
\hline $6 \%$ salty water & $3.87 \pm 0.03^{\mathrm{Ea}}$ & $3.32 \pm 0.14^{\mathrm{Db}}$ & $2.61 \pm 0.14^{\mathrm{BCb}}$ & $2.31 \pm 0.28^{\mathrm{Ab}}$ & $2.82 \pm 0.17^{\mathrm{Cb}}$ & $2.58 \pm 0.09^{\mathrm{ABCb}}$ & $2.66 \pm 0.05^{\mathrm{BCb}}$ & $2.52 \pm 0.17^{\mathrm{ABb}}$ \\
\hline $10 \%$ NEW & $3.89 \pm 0.03^{\mathrm{Da}}$ & $2.71 \pm 0.16^{\mathrm{Ca}}$ & $2.15 \pm 0.22^{\mathrm{BCa}}$ & $1.88 \pm 0.11^{\mathrm{BCa}}$ & $1.94 \pm 0.17^{\mathrm{BCa}}$ & $1.38 \pm 0.40^{\mathrm{ABa}}$ & $1.79 \pm 0.36^{\mathrm{BCa}}$ & $0.73 \pm 1.26^{\mathrm{Aa}}$ \\
\hline
\end{tabular}

$\mathrm{AB}$ : Values followed by the same letter in the same row are not significantly different $(\mathrm{P}<0.05)$; ab: Values followed by the same letter in the same column are not significantly different $(\mathrm{P}<0.05) ;{ }^{*}$ : Data are reported as mean \pm standard deviation

Table 3- Efficacy of treatment solutions (10\% NEW and $6 \%$ salty water) against yeast-mold load on surface of dried figs during the storage time*

\begin{tabular}{|c|c|c|c|c|c|c|c|}
\hline \multirow{3}{*}{$\begin{array}{l}\text { Treatment } \\
\text { Solution }\end{array}$} & \multicolumn{7}{|c|}{ Storage Time (Month) } \\
\hline & $\begin{array}{c}\text { Before } \\
\text { washing }\end{array}$ & $\begin{array}{c}\text { After } \\
\text { washing }\end{array}$ & 1 & 2 & 4 & 5 & 6 \\
\hline & \multicolumn{2}{|c|}{$\begin{array}{l}\text { Yeast-mold count } \\
\left(\log c f u g^{-1}\right)\end{array}$} & \multicolumn{4}{|c|}{ Yeast-mold count $\left(\log c f u g^{-1}\right)$} & \\
\hline Control & $3.34 \pm 0.47^{\mathrm{Ba}}$ & $3.36 \pm 0.46^{\mathrm{Bb}}$ & $3.01 \pm 0.29^{\mathrm{ABb}}$ & $2.81 \pm 0.60^{\mathrm{ABc}} 2.78 \pm 0.40^{\mathrm{ABb}}$ & $2.82 \pm 0.30^{\mathrm{ABb}}$ & $2.47 \pm 0.53^{\mathrm{ABb}}$ & $1.95 \pm 1.25^{\mathrm{Aa}}$ \\
\hline $6 \%$ salty water & $3.07 \pm 0.04^{\mathrm{Ea}}$ & $2.89 \pm 0.20^{\mathrm{DEab}}$ & $2.48 \pm 0.10^{\mathrm{CDEa}}$ & $1.9 \pm 0.25^{\mathrm{BCb}} \quad 2.06 \pm 0.63^{\mathrm{BCab}}$ & $2.34 \pm 0.22^{\mathrm{CDab}}$ & $1.47 \pm 0.42^{\mathrm{ABab}}$ & $0.97 \pm 0.66^{\mathrm{Aa}}$ \\
\hline $10 \% \mathrm{NEW}$ & $3.08 \pm 0.03^{\mathrm{Ea}}$ & $2.6 \pm 0.28^{\mathrm{DEa}}$ & $2.10 \pm 0.21^{\mathrm{CDa}}$ & $0.96 \pm 0.26^{\mathrm{ABa}} 1.5 \pm 0.49^{\mathrm{BCa}}$ & $1.32 \pm 0.86^{\mathrm{ABCa}}$ & $0.77 \pm 0.67^{\mathrm{ABa}}$ & $0.5 \pm 0.69^{\mathrm{Aa}}$ \\
\hline
\end{tabular}

${ }^{\mathrm{AB}}$ : Values followed by the same letter in the same row are not significantly different $(\mathrm{P}<0.05)$; ${ }^{\text {ab }}$ : Values followed by the same letter in the same column are not significantly different $(\mathrm{P}<0.05) ;{ }^{*}$ : Data are reported as mean \pm standard deviation

The number of MAB was decreased by $81 \%$ in the group washed with $10 \%$ NEW after 6 months of storage. In the same period, the number of MAB was decreased by $35 \%$ in the group washed with $6 \%$ salty water (Table 2). The yeast-mold count was decreased by $69 \%$ in the group washed with $10 \% \mathrm{NEW}$ after 2 months storage. In the same period, the yeast-mold count was decreased by $38 \%$ in the group washed with $6 \%$ salty water (Table 3 ). 
The rate of decrease in yeast-mold load in fig samples washed with $10 \%$ NEW in the 2 nd month was $69 \%$, but this rate decreased in the third month. The reason for this decrease is that the storage conditions are not controlled and the water activities of the stored fig samples increase from aw 0.69 to 0.78 due to seasonal changes (Figure 1). Therefore, since the 2 nd month of the storage, there have been fluctuations in the yeast-mold number of the stored figs due to the fluctuation in water activity. The fluctuation in water activity and yeast-mold count of fig samples washed with $10 \%$ NEW was also observed in fig samples stored under the same conditions and washed with $6 \%$ salty water. In general, the lowest water activity required for bacterial growth is aw 0.85, while this value for fungi is aw 0.65 (Manolopoulou et al. 2017). Therefore, the fluctuations between aw 0.6 and 0.8 of the water activities values of figs in storage conditions did not affect the MAB load as much as the yeast mold number. As a result, $10 \% \mathrm{NEW}$ is significantly $(\mathrm{P}<0.05)$ more effective than $6 \%$ salty water at all the storage periods for all microorganisms.

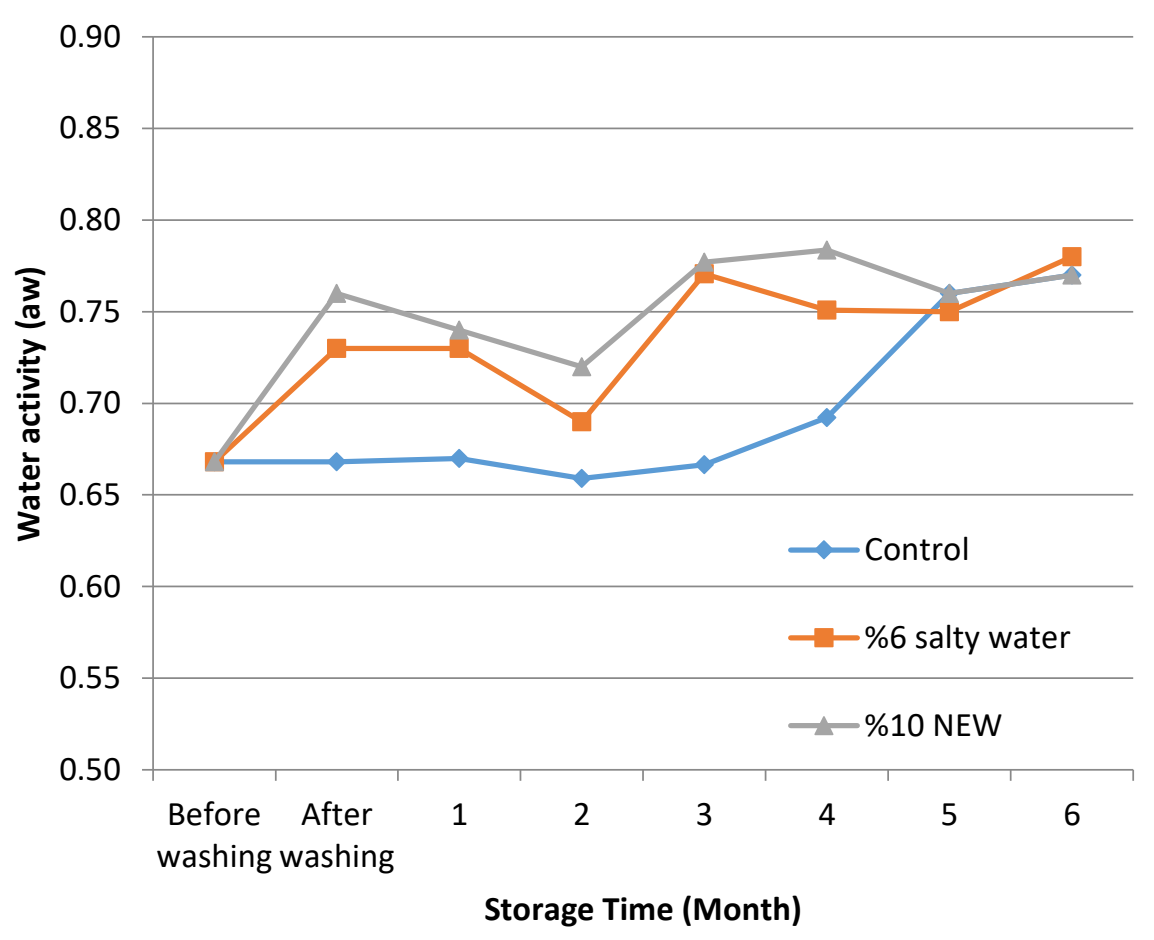

Figure 1- Water activities changes on threated figs during the storage period

Deza et al. (2003) reported a more reduction than $4 \log$ for Escherichia coli O157:H7, Salmonella enteritidis and Listeria monocytogenes on tomato surfaces exposed to NEW (pH: 7.99-8.15, ORP:745-771 mV, Cl:86-93 mg L-1) for 1 min. Graça et al. (2011) explored sanitizing effect of NEW (pH: 8.39, ORP:753 mV, Cl:50 mg L-1) containing $50 \mathrm{mg} \mathrm{L}^{-1}$ of active chlorine for Escherichia coli, Listeria innocua and Salmonella choleraesuis on fresh-cut apples. They reported that all microorganisms tested on apple slices were reduced by about $1.50 \mathrm{log}$ in $5 \mathrm{~min}$. Torlak (2014) observed a reduction of 1.98 log spore counts of Alicyclobacillus acidoterrestris on apples surfaces exposed to NEW (pH: 7.52, ORP:770 mV, Cl:50 mg L ${ }^{-1}$ ) for $1 \mathrm{~min}$. In all of three studies using NEW above, the materials and bacteria that were tested and NEW exposure durations, are different. Therefore, the low bacterial inactivation rate in the study that has longer NEW treatment duration from these three studies may arise from difference of the materials and bacteria that were tested. Graça et al. (2011) reported that the structure of surfaces of materials that were tested can likely affects resistance of microorganism to detachment by washing agents and to inactivation by antimicrobial agents. Since the surface of figs used in our study is not smooth like that of tomato, the inactivation power of $10 \%$ NEW may have decreased. Graça et al. (2011) also indicated that chlorine reacts with organic matter and some ingredients from tissues of cut fruit surfaces, diminishing its efficiency which does not occur in vegetable). If fig had been a smoother surface and less organic matter on its surface, it would have been obtained a more microbial reduction than $3.16 \log$ for MAB and $\geq 2.1 \log$ for yeast and mold.

In this study, the microbial inactivation power of $10 \% \mathrm{NEW}$ may also be affected from its application temperature $\left(50{ }^{\circ} \mathrm{C}\right)$. Yamaner et al. (2016) reported that while NEW (5\%, $\left.33.9 \mathrm{mg} \mathrm{L}^{-1}\right)$ application for 1 min led a reduction of $0.5 \mathrm{log} \mathrm{cfu}_{\mathrm{mL}}^{-1}$ on spores of $A$. flavus at $22{ }^{\circ} \mathrm{C}$, the numbers of spores of $A$. flavus were reduced more than $6 \log \mathrm{cfu} \mathrm{m}^{-1} \mathrm{by} \mathrm{NEW}\left(33.9 \mathrm{mg} \mathrm{L}^{-1}\right.$ ACC) application for 1 at $50{ }^{\circ} \mathrm{C}$. It has been showed that a higher temperature helped $\mathrm{EW}$ to more effectively inactive microorganisms. Consequently, the duration and way of application (spray, dip, or others), pH, ACC, ORP, temperatures of NEW are just some variables that can be combined to find the better results of NEW application (Athayde et al. 2018). 
Although there is no study on antimicrobial effect of electrolyzed water for fig, there are some studies on disinfection of fig by ozone exposure. Öztekin et al. (2006) exposed the dried figs to $10 \mathrm{ppm}$ ozone for $5 \mathrm{~h}$. While the total MAB count was decreased from 2.57 to $1.59 \log$ cfu g $^{-1}$, the yeast-mold count was reduced from 1.46 to $0.40 \log$ cfu g $^{-1}$ for 5-hour ozone exposure. They reported that as the ozone dosage and exposure duration were reduced, microbial inactivation rate also decreased. In addition, up to $2 \log$ reductions in the number B. cereus spores were obtained after 360 min-ozonation exposure above 1.0 ppm (Akbas et al. 2008). Given the processing and packaging duration of dried figs in an enterprise, 5-6 hours ozone treatment is too long and unsuitable for dried fig enterprises. As a result, NEW has shorter application duration than ozone for disinfection, more antimicrobial activity than salty water, low production and application cost. Also, it is an all-natural, organic, non-toxic, nonirritant, environmentally and ecologically safe sanitizing and disinfecting solution (Rahman et al. 2016), so 10\% NEW should be used in fig enterprises. Also, the results show that NEW should be used together with suitable high temperatures.

\section{3. Physicochemical characteristics of stored figs}

Water activities $\left(\mathrm{a}_{\mathrm{w}}\right.$ ) of washed figs (for $1 \mathrm{~min}$ at $50{ }^{\circ} \mathrm{C}$ ) just after $10 \% \mathrm{NEW}$ and $6 \%$ salty water treatment increased from 0.67 to 0.76 and 0.73 , respectively (Figure 1). In parallel with the $\mathrm{a}_{\mathrm{w}}$ value increasing as a result of the washing the dried figs, moisture content (\%), too, increased from 17.4 up to 23 just after $10 \%$ NEW and 6\% salty water treatment (Figure 2). It was detected that a decrease (from aw 0.76 to 0.72 for samples washed with NEW, from aw 0.73 to 0.69 for samples washed with $6 \%$ salty water) in water activity during storage up to $2^{\text {nd }}$ month and an increase from 2 nd to 6 th month exist. It was determined that the $\%$ humidity rate of the washed samples varied between $23 \%$ and $24.5 \%$. The changes in water activity and \% humidity may have resulted from ordinary storage conditions of the samples and seasonal changes. The $\mathrm{a}_{\mathrm{w}}$ and moisture values of figs in all three groups including the control group (which was not washed) showed slight fluctuations due to seasons changes in the storage period (Figures 1 and 2).

Water activity is an important parameter for the toxigenic fungus and mycotoxin formation during the harvest and processing of figs. Heperkan (2006) reported that Aspergillus section Nigri existed at a rate of 100\% in samples obtained from storage. The main ochratoxin A producers in figs in Turkey are A. carbonarius and A. niger (Karbancioglu-Güler \& Heperkan 2008). Also, it was reported that $A$. niger in dried figs was a fumonisin producer (Daskaya \& Heperkan 2010). The drying process of fig can lead to a selective and suitable environment for $A$. niger that are xerotolerant, for while the moisture content of fig diminishes, the sugar content increases (Heperkan et al. 2012). Consequently, the washing dried figs with $10 \%$ NEW to reduce the A. niger load in dried figs is important for human health.

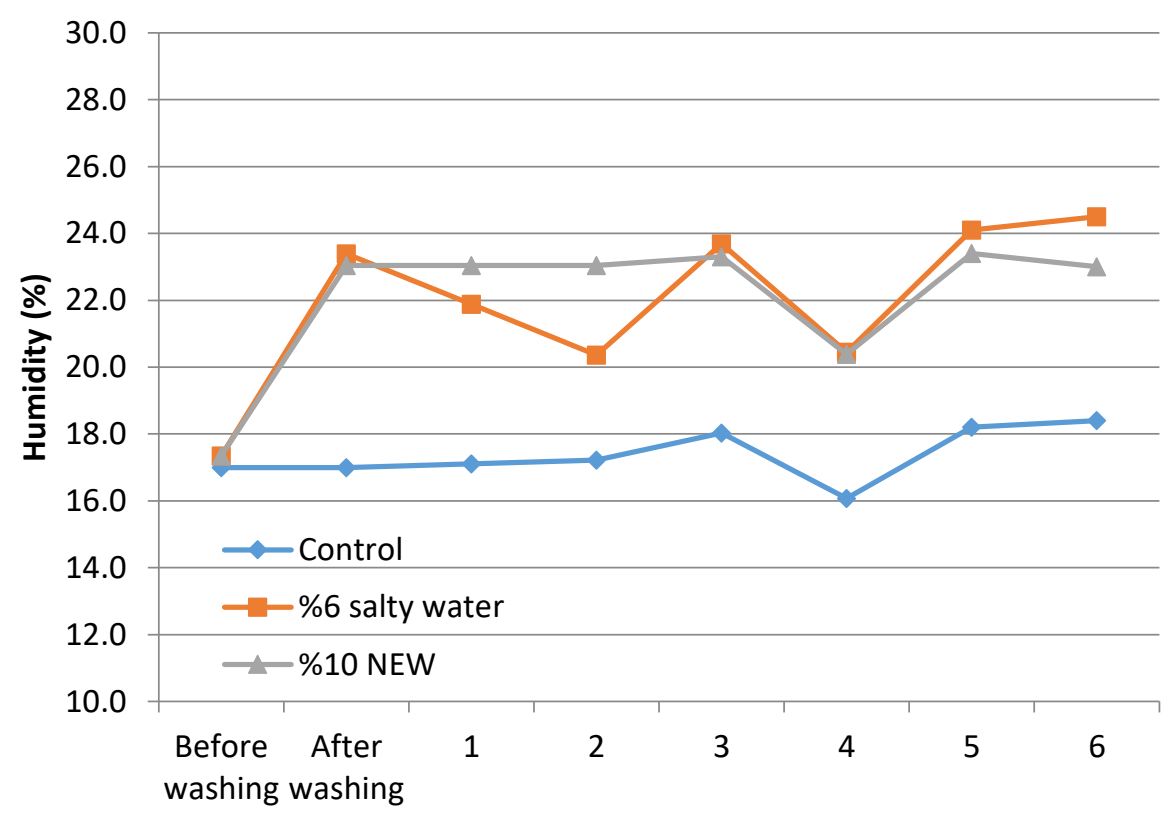

Storage Time (Month)

Figure 2- Changes in the moisture levels (\%) on dried figs during storage

Colour is one of the most important quality parameters for the consumers. Colour values were expressed as L (whiteness, brightness /blackness), a (redness/ greenness) and b (yellowness/blueness) (Table 4). It is seen that while the L-value of the figs in the control group is 63.23 , L-value of the dried figs washed with $10 \%$ NEW is 61.45 and L value of figs washed with $6 \%$ salty water is 62.39. The browning index of the control group, the samples washed with $6 \%$ salty water and $10 \%$ NEW were detected to vary between 85.52 - 76.43; 90.35 - 76.76 and 97.44 - 75.81, respectively during storage. The Browning index values obtained in this study correspond with the sun-dried fig browning index values reported by Manolopoulou et al. (2017). Also, in this study, 
B.I of figs washed with $10 \% \mathrm{NEW}$ is parallel to those of figs washed with $6 \%$ salty water, which is the standard practice. L $*$, a $*, \mathrm{~b} *$ and B.I values of all three groups are given in Table 4.

Table 4- Changes in the colour values during the storage period after the washing of dried figs

\begin{tabular}{|c|c|c|c|c|c|c|c|c|c|c|c|c|}
\hline \multirow{2}{*}{$\begin{array}{c}\text { Storage } \\
\text { time }\end{array}$} & \multicolumn{3}{|c|}{ Control } & \multicolumn{5}{|c|}{$6 \%$ Salty Water } & \multicolumn{4}{|c|}{$10 \% \mathrm{NEW}$} \\
\hline & $L^{*}$ & $a^{*}$ & $b^{*}$ & B.I & $L^{*}$ & $a^{*}$ & $b^{*}$ & B.I & $L^{*}$ & $a^{*}$ & $b^{*}$ & B.I \\
\hline 0.Month* & 63.23 & 9.77 & 33.95 & 85.52 & 62.39 & 9.55 & 35.07 & 90.35 & 61.45 & 10.36 & 36.31 & 97.44 \\
\hline 1. Month & 61.49 & 9.54 & 31.86 & 81.99 & 59.72 & 9.39 & 33.24 & 89.57 & 59.44 & 9.59 & 34.05 & 93.16 \\
\hline 2. Month & 61.94 & 9.61 & 29.98 & 75.73 & 60.32 & 9.82 & 32.11 & 85.26 & 60.45 & 9.84 & 32.72 & 87.01 \\
\hline 3. Month & 59.51 & 8.97 & 28.76 & 75.24 & 57.4 & 8.49 & 28.29 & 76.76 & 55.38 & 8.49 & 27.82 & 78.92 \\
\hline 4. Month & 58.71 & 8.48 & 27.89 & 73.32 & 56.83 & 8.39 & 27.28 & 74.46 & 57.43 & 8.33 & 27.88 & 75.22 \\
\hline 5. Month & 62.2 & 8.1 & 28.84 & 70.24 & 60.18 & 7.79 & 27.98 & 70.40 & 57.94 & 7.84 & 26.45 & 69.40 \\
\hline 6. Month & 57.71 & 9.005 & 28.14 & 76.44 & 54.81 & 8.69 & 26.77 & 76.76 & 53.48 & 8.16 & 25.97 & 75.81 \\
\hline
\end{tabular}

*: The sample taken after the washing, before the storage.

\section{Conclusions}

In this study, the efficiency of $10 \% \mathrm{NEW}$ and $6 \%$ salty water on microbial load on the surface and physicochemical properties of dried fig samples during the storage for six months was compared. Microbiological and physicochemical results show that washing figs with $10 \% \mathrm{NEW}$ for $1 \mathrm{~min}$ at $50{ }^{\circ} \mathrm{C}$ is better than $6 \%$ salty water for disinfection of figs. By its neutral pH level, electrolyzed water usage became a safer and easier alternative for food industry. The NEW is thought to be more effective alternative for the salty water used in fig plants. According to our current information, this study is the first report on the applicability of NEW in the controlling of the microbial population of dried figs and provides a scientific background for further experiments

\section{Acknowledgments}

I would like to thank to the Food Group at Erbeyli Fig Research Institute and Gebze Technic University. The author disclosed receipt of the following financial support for the research, authorship, and/or publication of this article: The author is thankful to financial supports by General Directorate of Agricultural Research, Turkey (Project No: TAGEM/GY/11/03/01/183).

\section{References}

Akbas M Y \& Ozdemir M (2008). Application of gaseous ozone to control populations of Escherichia coli, Bacillus cereus and Bacillus cereus spores in dried figs. Food Microbiology 25: 386-391. https://doi.org/10.1016/j.fm.2007.09.007

AOAC (1990). Official Methods of Analysis of the Association of Official Analytical Chemists, $15^{\text {th }}$ ed. Arlington, VA, USA

Athayde D R, Flores D R M, Silva J S, Silva M S, Genro A L G, Waqgner R, Campagnol P C B, Menezes C R \& Cichoski A J (2018). Characteristics and use of electrolyzed water in food industries. Intertional Food Research Journal 25(1): 11-16

Boudra H, Le Bars J, Le Bars P \& Dupuy J (1994). Time of Aspergillus flavus infectionand aflatoxin formation in ripening of figs. Mycopathologia 127: 29-33. https://doi.org/10.1007/bf01104008

Cemeroğlu B (2007). Gıda Analizleri. Gıda Teknolojisi Derneği Yayınları No. 34, Ankara

Daskaya C \& Heperkan D (2010). Fumonisin production by Aspergillus section Nigri from dried fig. In: Abstracts, $22^{\text {nd }}$ International ICFMH Symposium Food Micro 2010, August 30-September 3, Copenhagen, Denmark, pp. 147. DOI: 10.3109/15569543.2012.756524

Deza M, Araujo M \& Garrido M (2003). Inactivation of Escherichia coli O157:H7, Salmonella enteritidis and Listeria monocytogenes on the surface of tomatoes by neutral electrolyzed water. Letter in Applied Microbiology 37(6):482-487. https://doi.org/10.1046/j.1472765x.2003.01433.x

Ding T, Rahman S M E \& Oh D H (2011). Inhibitory effects of low concentration electrolyzed water and other sanitizers against foodborne pathogens on oyster mushroom. Food Control 22(2):318-22. https://doi.org/10.1016/j.foodcont.2010.07.030

Dychdala G R (1983). Chlorine and chlorine compounds. In: Block SS, editor. Disinfection, Sterilization, and Preservation. third ed. Lea and Febiger, Philadelphia. pp. 157-182

Frazier W C \& Westhoff D C (1988). Food Microbiology, fourth ed. McGraw-Hill, New York, pp. 185

Graça A, Abadias M, Salazar M \& Nunes C (2011). The use of electrolyzed water as a disinfectant for minimally processed apples. Postharvest Biology and Technology 61(2):172-177. https://doi.org/10.1016/j.postharvbio.2011.04.001

Guentzel J L, Lam K L, Callan M A, Emmons S A \& Dunham V L (2010). Postharvest management of gray mold and brown rot on surfaces of peaches and grapes using electrolyzed oxidizing water. International Journal of Food Microbiology 143:54-60. https://doi.org/10.1016/j.ijfoodmicro.2010.07.028

Hao J, Liu H, Liu R, Dalai W, Zhao R, Chen T \& Li L (2011). Efficacy of slightly acidic electrolyzed water (SAEW) for reducing microbial contamination on fresh-cut cilantro. Journal of Food Safety 31(1):28-34. https://doi.org/10.1111/j.1745-4565.2010.00261.x 
Heperkan D (2006). The importance of mycotoxins and a brief history of mycotoxin studies in Turkey, Special issue "Mycotoxins: hidden hazards in food". ARI 54: 18-27

Heperkan D, Morett A, Dikmen C D, Logrieco A F (2012). Toxigenic fungi and mycotoxin associated with figs in the Mediterranean area. Phytopathologia Mediterranea 51(1): 119-130 https://doi.org/10.14601/Phytopathol_Mediterr-9467

Hirayama Y, Asano S \& Watanabe K (2016). Control of Colletotrichum fructicola on strawberry with a foliar spray of neutral electrolyzed water through an overhead irrigation system. Journal of General Plant Pathology 82: 186-189. https://doi.org/10.1007/s10327-016-0667-6

Ileri Ç, Sezen I Y \& Dimoglo A (2006). Elektro-aktive asitli suyun bazı patojen mikroorganizmaların standart suşları üzerindeki etkisinin araştırılması. Mikrobiyoloji Bulteni 40: 317-324

Jardon-Xicotencatl S, Díaz-Torres R \& Marroquín Cardona A (2015). Detoxification of aflatoxin contaminated maize by neutral electrolyzed oxidizing water. Toxins 7(10): 4294-4314. https://doi.org/10.3390/toxins7104294

Karbancioglu-Güler F \& Heperkan D (2008). Natural occurrence of ochratoxin A in dried figs. Analytica Chimica Acta 617: $32-36$. https://doi.org/10.1016/j.aca.2008.01.009

Lee N Y, Kim N H, Jang I S, Jang S H, Lee S H, Hwang I G \& Rhee M S (2014). Decontamination efficacy of neutral electrolyzed water to eliminate indigenous flora on a large-scale of cabbage and carrot both in the laboratory and on a real processing line. Food Research International 64: 234-240. https://doi.org/10.1016/j.foodres.2014.05.053

Lehto M, Kuisma R, Kymäläinen H R \& Mäki M (2018). Neutral electrolyzed water (NEW), chlorine dioxide, organic acid-based product, and ultraviolet-C for inactivation of microbes in fresh-cut vegetable washing waters. The Journal of Food Processing and Perservation 42(1): 1-9. https://doi.org/10.1111/jfpp.13354

Len S V, Hung Y C, Chung D, Anderson J L, Erickson M C \& Morita K (2002). Effects of storage conditions and pH on chlorine loss in electrolyzed oxidizing (EO) water. The Journal of Agricultural and Food Chemistry 50(1): 209-212. https://doi.org/10.1021/jf010822v

Manolopoulou E, Tsiavtari E \& Demopoulos V (2017). Sun drying and hot air drying of figs: performance evaluation. Acta Horticulture 1173: 341-346. https://doi.org/10.17660/actahortic.2017.1173.59

Messer J W, Rice E W, Johnson C H \& William M G (2000). Spread plate technique. In Robinson RK, Batt CA, Patel PD (Eds.) Encyclopedia of food microbiology. Academic Press, 3 (0-12-227070-3), pp. 2156-2160

Mohammadi A, Shahin R, Zahra E D \& Alirez K (2008). Kinetic models for colour changes in kiwi fruit slices during hot air drying. World Journal of Agricultural Sciences 4(3): 376- 383

Navarro-Rico J, Artés-Hernández F, Gómez P A, Núñez-Sánchez M A, Artés F \& Martínez-Hernández G B (2014). Neutral and acidic electrolysed water kept microbial quality and health promoting compounds of fresh-cut broccoli throughout shelf life. Innovative Food Science and Emerging Technologies 21: 74-81. https://doi.org/10.1016/j.ifset.2013.11.004

Öztekin S, Zorlugenç B \& Zorlugenç F K (2006). Effects of ozone treatment on microflora of dried figs. Journal of Food Engineering 75: 396399. https://doi.org/10.1016/j.jfoodeng.2005.04.024

Rahman S M E, Ding T \& Oh D H (2010). Effectiveness of low concentration electrolyzed water to inactivate foodborne pathogens under different environmental conditions. International Journal Food Microbiology 139(3): 147-153. https://doi.org/10.1016/j.ijfoodmicro.2010.03.020

Rahman S M E, Khan I \& Oh D H (2016). Electrolyzed water as a novel sanitizer in the food industry: Current trends and future perspectives. Comprehensive Reviews in Food Science and Food Safety 15: 471-490. https://doi.org/10.1111/1541-4337.12200

Stover E, Aradhya M, Crisosto C H \& Ferguson L (2007). Overview of the California fig industry and new interest in varieties for fresh fruit. In: Proceedings of the California Plant and Soil Conference, 6-7 February, Sacramento, CA. California Chapter, American Society of Agronomy pp. 169-175

Torlak E (2014). Inactivation of Alicyclobacillus acidoterrestris spores in aqueous suspension and on apples by neutral electrolyzed water. International Journal Food Microbiology 185: 69-72. https://doi.org/10.1016/j.ijfoodmicro.2014.05.022

TUIK 2018/2019: http://www.tuik.gov.tr/PreTablo.do?alt_id=1001

White G C (1998. Handbook of chlorination and alternative disinfectants ( $4^{\text {th }}$ edn). John Wiley \& Sons, New York

Yamaner C, Ayvaz M, Konak R, Tan N, Kösoglu İ \& Dimoglo A (2016). Efficacy of neutralised electrolysed water and mild heat against foodborne pathogens isolated from Ficus carica. Italian Journal of Food Science 28: 208-220. https://doi.org/10.14674/1120$1770 /$ ijfs.v260

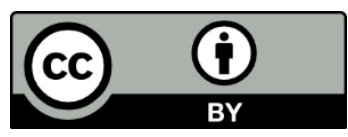

(C) 2022 by the author(s). Published by Ankara University, Faculty of Agriculture, Ankara, Turkey. This is an Open Access article distributed under the terms and conditions of the Creative Commons Attribution (CC BY) license (http://creativecommons.org/licenses/by/4.0/), which permits unrestricted use, distribution, and reproduction in any medium, provided the original work is properly cited. 